\title{
DEVELOPMENT AND APPLICATION OF AMBIENT AIR QUALITY STANDARDS
}

Petro Terblanche, Louise Uys, Riëtte Nel

Research Institute for Environmental Diseases,

Medical Research Council, Private Bag X385

Pretoria, 0001

\begin{abstract}
:
Ambient air quality standards $(A Q S)$ are values which indicates a "safe" level for the majority of the population and which have regulatory powers. In other words, AQS specify maximum allowable concentrations of air pollutants in outdoor areas to which the general public has access. These standards were determined through intensive investigations using epidemiological data, controlled exposure data, animal studies and occupational health data. They form the baseline for air pollution control. Although South Africa has not implemented standards, we have adopted the USA standards as guidelines. The six regulatory pollutants included in the USA standards are: $\mathrm{SO}_{2}, \mathrm{NO}_{x}, \mathrm{CO}, \mathrm{PM} 10, \mathrm{O}_{3}$ and lead.
\end{abstract}

\section{OPSOMMING:}

Lugkwaliteitstandaarde (LS) bestaan uit waardes wat 'n "veilige" blootstelling vir die meerderheid van mense in 'n gegewe populasie verseker. Met ander woorde LS spesifiseer maksimum toelaatbare konsentrasies van lugbesoedelstowwe in buitenshuise areas waarmee die publiek in aanraking kom. Hierdie standaarde het wettige beheermagte. Lugkwaliteitstandaarde word bepaal deur intensiewe navorsing deur gebruik te maak van epidemiologiese data, beheerde blootstellingsstudies, diere-eksperimente en beroepsgesondheidsdata. Hierdie standaarde vorm die basis vir lugbesoedelingsbeheer. Alhoewel Suid-Afrika nie lugkwaliteitstandaarde geimplementeer het in ons lugbesoedelingsbeheerwetgewing nie het ons wel die VSA standaarde aangeneem as riglyne. Die huidige ses reguleerbare besoedelstowwe is: $\mathrm{SO}_{2}, \mathrm{NO}_{x}, \mathrm{CO}_{2}$ $P M_{10}, \mathrm{O}_{3}$ en lood.

\section{INTRODUCTION}

The adoption of Air Quality Standards (AQS) is one of several means of regulatory control of air pollution. Air quality standards must best be established to protect the public from 24 hour exposure, each day for the lifetime of the entire population, including the very young, the elderly and all other potential high risk groups. It is therefore understandable that the establishment of AQS is a very difficult task considering the economic, social and health implications of such standards. ${ }^{1}$

The AQS of the USA were adopted in 1972 following the air pollution episodes in Donora 1948 and London 1952. The first standard for community air pollution was set in 1948 for black smoke using the Ringelmann Chart. ${ }^{2}$ Following that, the federal law adopted primary and secondary standards for six pollutants. In order to understand the development and application of the AQS, one has to distinguish between guidelines, threshold values and standards. Guidelines are values which indicate a recommended safe value but have no regulatory powers. A threshold is a value which cannot stand alone but rather should be related to a specific effect, not to general effects, since in the latter instance there is a family or series of "thresholds" one for each effect. Standards are values which indicate a "safe" level for the majority of a population in respect to general health effects and have regulatory powers. ${ }^{2}$

The general methods used to determine standards are: epidemiological studies, controlled exposure studies, animal studies and occupational health studies. ${ }^{3}$

There are currently six criteria pollutants in the AQS of the USA. These are: Carbon monoxide (CO), Nitrogen oxides $\left(\mathrm{NO}_{\mathrm{x}}\right)$, Ozone $\left(\mathrm{O}_{3}\right)$, Sulphur oxides $\left(\mathrm{SO}_{\mathrm{x}}\right)$, respirable particulate matter $\left(\mathrm{PM}_{10}\right)$ and lead $(\mathrm{Pb})$. The standards for each, including the process used to determine the specific values, are discussed in this paper. ${ }^{23,45,6,7}$

\section{CURRENT AIR QUALITY STANDARDS (USA)}

The AQS are reviewed at 5-year intervals. During the past 10 -years the following changes were made to the original standards set in 1972:

- Review of the $\mathrm{O}_{3}$ standard was completed in 1979. The standard was raised from $0,08 \mathrm{ppm}$ to $0,12 \mathrm{ppm}$, maximum 1-hour concentration;

- The non-methane hydrocarbon standard was revoked January 1983 due to the fact that it has no direct health effects but was merely used as indicator of photochemical air pollution formation;

- The CO standard review was completed in September 1985. No change was made to the primary standard, the secondary standard was revoked;

- The $\mathrm{NO}_{x}$ standard was reaffirmed in June 1985;

- Major revisions to the PM standard were made in June, 1987. The primary and secondary standards are identical and based on particles less than or equal to $10 \mu \mathrm{m}$ in diameter rather than total suspended particulates (TSP). The possibility for a fine particle standard (less than $2,5 \mu \mathrm{m}$ ) is being investigated;

- The current standards for $\mathrm{SO}_{\mathrm{x}}$ are being re-evaluated and the addition of a 1-hour $\mathrm{SO}_{2}$ primary standard of $0,4 \mathrm{ppm}$ is considered;

- The primary and secondary standards for lead are unchanged since October 1978.

Since 1984 the secondary standard (aimed to protect the environment) for all the criteria pollutants were changed to be the same as the primary standards which are aimed to protect human health. ${ }^{4}$ 


\subsection{Carbon Monoxide}

\section{Standard}

$10 \mathrm{mg} / \mathrm{m}^{3}(9 \mathrm{ppm})$ 8-hour average not to be exceeded more than once per year.

$40 \mathrm{mg} / \mathrm{m}^{3}$ (35 ppm) 1-hour average not to be exceeded more than once per year.

This pollutant is an example in which laboratory studies have been extremely useful and relevant in developing and supporting the standards. ${ }^{3}$ Of the six primary pollutants, this is the only one for which there is a biologic measure of dose, namely carboxyhemoglobin $(\mathrm{COHb})$ level in the blood. The dose-effect relationship between levels of $\mathrm{CO}$ and health effects has been established. ${ }^{3}$ The present 8 hour and 1-hour standards seem quite adequate and should be protective even to exercising individuals. ${ }^{3}$

\subsection{Ozone}

\section{Standard}

$235 \mu \mathrm{g} / \mathrm{m}^{3}$ (0,12 $\left.\mathrm{ppm}\right)$ 1-hour average.

An evaluation of the effects of ozone and photochemical oxidants is fraught with many difficulties compared with an evaluation of carbon monoxide. ${ }^{3}$ Some of the factors that confound the evaluation are a naturally occurring $\mathrm{O}_{3}$ layer in the upper atmosphere, some of which can be drawn down to terrestrial levels and produce levels above the primary standard; similarly hydrocarbons from natural sources can interact with atmospheric components to produce relatively high $\mathrm{O}_{3}$ levels; furthermore, $\mathrm{O}_{3}$ is not the only active component and it may occur in conjunction with other regulated compounds; and lastly, $\mathrm{O}_{3}$ produced in one area can be transported over considerable distances. ${ }^{3,6}$ Thus, controls should be considered on a regional or national basis rather than on purely local conditions. ${ }^{3}$ An additional problem is that the reliability and accuracy of the KI method that has been used in Los Angelos County and elsewhere to measure total oxidants have been scriously questioned, and this places all the environmental levels reported in earlier studies in doubt. ${ }^{6}$

Ozone is a strongly oxidising material that is a component of the complex mix of photochemical air pollution. ${ }^{6}$ The level of $\mathrm{O}_{3}$ is used as an indicator of the amount of total oxidants in the atmosphere. ${ }^{6}$ The $\mathrm{O}_{3}$ standard were developed as a result of animal toxicological studies, human controlled exposure studies and epidemiological studies. The majority of results influencing the decision about the final standard adopted is given below.

Under the conditions prevailing in the areas where studies were conducted, adverse health effects, as shown by impairment of performance of student athletes, occurred over a range of hourly average oxidant concentrations from 60 to $590 \mu \mathrm{g} / \mathrm{m}^{3}$ (0,03 to $\left.0,3 \mathrm{ppm}\right){ }^{3}$

An increased frequency of asthma attacks in a small proportion of subjects with this disease was shown on days when oxidant concentrations exceeded peak values of 250 $\mu \mathrm{g} / \mathrm{m}^{3}(0,13 \mathrm{ppm})$, a level that would be associated with an hourly average concentration ranging from 100 to 120 $\mu \mathrm{g} / \mathrm{m}^{3}$ (0,05 to $\left.0,06 \mathrm{ppm}\right){ }^{6}$ Adverse health effects, as manifested by eye irritation, were reported by subjects in several studies when photochemical oxidant concentrations reached instantaneous levels of about $200 \mu \mathrm{g} / \mathrm{m}^{3}(0,10$ ppm), a level that would be associated with an hourly average concentration ranging from 60 to $100 \mu \mathrm{g} / \mathrm{m}^{3}(0,03$ to $0,05 \mathrm{ppm}){ }^{3,6}$

Adverse effects on sensitive vegetation were observed from exposure to photochemical oxidant concentrations of about $100 \mu \mathrm{g} / \mathrm{m}^{3}$ (0,05 ppm) for 4 hours. ${ }^{6}$ Adverse effects on materials from exposure to photochemical oxidants have not been precisely quantified, but have been observed at the levels presently occurring in many urban atmospheres. $^{6}$

Based on the above information for $\mathrm{O}_{3}$ standard was set at $0,12 \mathrm{ppm}$ in 1979. This value does not seem to be conservative in respect to levels at which health effects were observed but does take the natural background levels into account.

\subsection{Nitrogen oxides}

\section{Standard}

$100 \mu \mathrm{g} / \mathrm{m}^{3}$ (0,05 ppm) Annual arithmetic mean.

As with oxidants, nitrogen oxides pose a number of problems with respect to evaluating their effect on health. ${ }^{3}$ They tend to occur with other pollutants, and in photochemical air pollution they are only a part of the many components. ${ }^{7}$ Thus, as with $\mathrm{O}_{3}$, exposures of human subjects to pure $\mathrm{NO}_{2}$ in chambers may under- or overestimate the effect that might be seen with complex mixtures. ${ }^{3}$ Although $\mathrm{NO}$ interacts with $\mathrm{O}_{3}$, to produce $\mathrm{NO}_{2}, \mathrm{NO}_{2}$ alone appears to be the oxide responsible for effects on health. ${ }^{3}$

There is ample evidence that high levels (above $150 \mathrm{ppm}$, $282 \mathrm{mg} / \mathrm{m}^{3}$ ) of $\mathrm{NO}_{2}$ can be lethal. ${ }^{3}$ Exposures that involve moderate levels ( 50 to $150 \mathrm{ppm}, 94$ to $282 \mathrm{mg} / \mathrm{m}^{3}$ ) can produce chronic lung disease, such as bronchiolitis obliterans, but the precise levels of acute exposurf required to do this are not clear. ${ }^{6}$ Adverse health effects, as evidenced by a greater incidence of acute bronchitis among infants and school children, have been observed, under the conditions prevailing in the areas where studies were conducted, when the mean 24-hour $\mathrm{NO}_{2}$ concentration, measured by the Jacobs-Hochheiser method, over a 6-month period, varied from 118 to $156 \mu \mathrm{g} / \mathrm{m}^{3}(0,063$ to $0,083 \mathrm{ppm}){ }^{3,6}$ On an annual basis, a maximum 24 -hour average as low as $284 \mu \mathrm{g} / \mathrm{m}^{3}(0,15 \mathrm{ppm})$ would be expected to be associated with a 6-month mean of 118 $\mu \mathrm{g} / \mathrm{m}^{3}{ }^{6}$. Adverse health effects, as evidenced by an increased incidence of acute respiratory disease, have been observed in family groups when the mean 24-hour $\mathrm{NO}_{2}$ concentration measured over a 6-month period was between 117 and $205 \mu \mathrm{g} / \mathrm{m}^{3}(0,062$ and 0,109 ppm) and the mean suspended nitrate level was $3,8 \mu \mathrm{g} / \mathrm{m}^{3}$ or greater. $^{6}$

Adverse effects on vegetation such as leaf abscission and decreased yield of navel oranges have been observed 
during fumigation studies when the $\mathrm{NO}_{2}$ concentration (measured by the continuous Saltzman Method) was 470 $\mu \mathrm{g} / \mathrm{m}^{3}(0,25 \mathrm{ppm})$ during an 8-month period. ${ }^{6}$

Based on the above information the AQS for $\mathrm{NO}_{\mathbf{x}}$ was developed.

\subsection{Sulphur Dioxide $\left(\mathrm{SO}_{2}\right)$}

\section{Standard}

$80 \mu \mathrm{g} / \mathrm{m}^{3}$ (0,03 ppm) Annual arithmetic mean. $365 \mu \mathrm{g} / \mathrm{m}^{3}(0,14 \mathrm{ppm})$ 24-hour average not to be exceeded more than once per year.

The $\mathrm{SO}_{2}$ standard was developed from results of animal experimental studies, the London episodes of 1952 , epidemiological studies and controlled exposure studies. ${ }^{3}$

Both the long term and short term effects of $\mathrm{SO}_{2}$ were taken into account when setting the standards.

\subsection{Particulate Matter $\left(\mathrm{PM}_{10}\right)$}

Standard

$50 \mu \mathrm{g} / \mathrm{m}^{3}$ Annual arithmic mean.

$150 \mu \mathrm{g} / \mathrm{m}^{3}$ 24-hour average is not to be exceeded more than once per year.

The $\mathrm{PM}_{10}$ standard was developed directly from the old TSP 24-hour standard of $260 \mu \mathrm{g} / \mathrm{m}^{3.5}$. The previous standard for particulates is based on total suspended particulates collected on filters by high-volume sampling and measured gravimetrically. ${ }^{2}$ At times, analyses have been made on the filters for water-soluble sulphates, nitrates and occasionally for trace metals. ${ }^{5}$ The hi-vol method collects both the fine fraction, sometimes referred to as the "Mass respirable particulates" (MRP), as well as the coarse fraction..$^{5}$ There appears to be a bimodal distribution of the collected airborne particles, with the separation being in the range of $2-4 \mu \mathrm{m}$ when based on volume or mass. ${ }^{5}$ The smaller particles tend to contain the sulphate fraction that has been produced from the converTion of $\mathrm{SO}_{2}{ }^{5}$. The larger particles are generally the result of abrasive or grinding actions that have thrown the material into the air. ${ }^{5}$ The larger particles are less likely to be deposited deep in the respiratory system, but can be deposited in the nose and naso-pharynx, where they may have direct action, or be swallowed and have an effect in the gastrointestinal tract, or be absorbed and have a systemic effect like lead. ${ }^{35}$ The TSP standard set in 1972 were developed from data obtained from epidemiological studies, animal studies and exposure studies. The TSP standard was replaced by the $\mathbf{P M}_{10}$ standard as a primary standard due to the fact that particulate matter with a diameter of less than $10 \mu \mathrm{m}$ is respirable and is therefore imposing a real health risk. ${ }^{5}$ Various modelling program mes including air characterisation studies were used to evaluate the fraction of TSP which could be classified as $\mathrm{PM}_{10}{ }^{5}$ This data was also considered when developing the current $\mathbf{P M}_{10}$ standard.

\subsection{Lead}

\section{Standard}

\section{$1.5 \mu \mathrm{g} / \mathrm{m}^{3}$ Quarterly Average.}

The lead standard is based on toxicological animal studies and human epidemiological studies. ${ }^{3}$ The primary reason for including lead as a criteria pollutant is the potential risk to child health from exposure to lead as a result of motor vehicle pollution and industrial processes. ${ }^{3}$

\section{THE SOUTH AFRICAN SITUATION}

South Africa has adopted the USA AQS as guidelines only. This implies that the "safe" values we are referring to have no legal powers in this country. Without a national monitoring network for SA the adoption of standards is not relevant. Effective air pollution control begins with air pollution monitoring - you can only control something you know. The economic implications of introducing AQS for SA are mind boggling. Nevertheless we do have to start evaluating the adequacy of our current control system to protect human health and the environment and one way to do this is to compare our air pollution data with the USA standards.

\section{REFERENCES}

1. Terblanche, A.P.S. Air Pollution and Human Health. Presented at: Man and the Environment Conference, Skukuza, May 1990.

2. Lippmann, M. and Schlesinger, R.B. Chemical Contamination in the Human Environment. Oxford Univ. Press, New York, 1979.

3. Ferris, B.G. Health Effects of Exposure to Low Levels of Regulation Pollutants. JAPCA 28: 482-487, 1978.

4. USA Environmental Protection Agency. Status of National Ambient Air Quality Standards. April 1989.

5. Mathai, V, Stonefield, D.H., and Watson, J.G. PM-10: Implementation of Standards. JAPCA 38(7): 888-894, 1988.

6. USA Environmental Protection Agency. Air Quality Criteria for Photochemical Oxidants. March 1970.

7. USA Environmental Protection Agency. Air Quality Criteria for Nitrogen Oxides. January 1971. 


\section{TECHNICAL NOTE:}

\section{CHAMBER OF MINES' VEGETATION UNIT PLAYS MAJOR ROLE IN REHABILITATION}

Of some 8000 hectares of minedump surface area on the Witwatersrand, the Vegetation Unit of the Environmental Management Services Section of the Chamber of Mines has been involved in the rehabilitation of some 5000 hectares.

The Vegetation Unit, set up by members of the Chamber of Mines in 1960 as a contractor and adviser on rehabilitation and of pollution control, initially concentrated all its work on gold mine sand dumps and slimes dams.

Its services were not entirely restricted to members of the Chamber and could consequently be made available to anyone requiring assistance and expertise in the field.

Its base was also systematically broadened to include rehabilitation work on mines other than gold, and more recently into the field of opencast colliery rehabilitation.

But what hasn't changed over the years, says environmental affairs manager John Easton, is that the unit remains a non-profit organisation providing a service to the mining industry. Its mission is to provide members and others with a service that will minimise pollution during operations and allow them to close with the least possible inconvenience and cost.

There is today no section of the mining industry in which the Vegetation Unit has not been active. Its services are tailored to the needs of each individual mine - from supervising the mine's own labourforce to perform the rehabilitation and pollution-control work, to a complete turnkey operation which includes groundwork, fertilisation, seeding and engineering services. Where necessary contractors are engaged to provide the large machines for the groundwork. The operations manager is Brian Dawson.

The unit, Easton says, has over the years been instrumental in the framing of guidelines for dump construction, maintenance and closing-down procedures for both metalliferous and colliery dumps, vegetation establishment on colliery dumps and residue deposits, opencast rehabilitation, geohydrology, and most recently procedures to meet the statutory requirements for environmental management.

The guidelines on vegetation were prepared entirely by the Vegetation Unit and those on opencast rehabilitation are used by the Government Mining Engineer as a standard for measuring a company's performance in terms of the legislation.

For 30 years the Chamber of Mines has been in the midst of environmental issues, but its role was not always generally recognised, Easton says. It was only through participation in shows in places such as Middelburg, Bethal, Ermelo and Witbank, that the public's perception started changing, and greater understanding was reached, particularly with the farming community.
As a result of the Vegetation Unit's experience in the field, it was appointed as accredited contractor and adviser to the Government Mining Engineer in his programme to rehabilitate defunct mines, and also to the Department of Water Affairs. "Because of our mission to expedite mine closure without undue fuss, we are keen to establish a vegetation cover which is durable," Easton says.

He says that the Vegetation Unit is not in the business of providing short-term guarantees, but rather long-term ones, so that after closure of a mine, the good name of the client can be protected so that where mining permits are required at a later stage, they are not prejudiced.

"We believe that in the not too distant future a company's environmental record will contribute to its competitiveness in mining," Easton says.

He points out that overseas, if a mining licence is up for tender, part of the tender evaluation is on a company's environmental record. "And because we believe that this will in future also become the norm in South Africa, we have endeavoured to produce long-term solutions, particularly in respect of toxic waste, where we have a record of success based on a two-phase procedure," he says, being:

Treatment of the waste itself to remove toxicity and rendering it suitable for vegetation growth, such as the leaching technique for pyritic gold slimes. This technique was developed by the Chamber of Mines in the late 1950s and uses a fine spray of water to wash sulphuric acid, which is the product of the oxidation of pyrites, down below the root zone and into the lower alkaline zone; and

Establishing vegetation which will prevent erosion, either using useful indigenous grass species or, where not available, other species which will prevent erosion. Creation of a stable surface allows the natural incursion of species, often starting with those low on the ecological ladder and followed by progression to more dominant species.

Many of the older mine sites on the Reef, Easton says have shown the development of a true surface covering of kweek grass, thatching grass and Eragrostis Curvula (weeping lovegrass). Of these three, kweek is useful as a creeping grass which binds the soil to prevent erosion.

Thatching grass has good fire tolerance, while Eragrostis is the least useful as it requires constant input of nutrients to maintain viability. Without this input it becomes moribund and tends to be a major fire hazard. Also its erosion protection potential is low because of its tufted growth habit. Because it is the aim to provide durable cover requiring minimum maintenance. Easton says, we have tended to reduce Eragrostis quantities in mixtures over the years. The last ten years have also seen a reduction of exotic species of vegetation which were not viable in the long term.

"We encourage the incursion of Hyparrhenia by the use of Hyparrhenia mulch spread over the soil surface. It is cut when seeding and the seed load is therefore spread over 
the surface of the waste. After a few years we find Hyparrhenia plants sprouting. This method is more successful than the sowing of Hyparrhenia seed as part of a mixture," he adds.

Other species such as legumes sown at the same time as other varieties have not proved very successful. Legumes sown later are successful and have a nitrogen-fixing capacity which saves on the cost of artificial fertilizer mixtures. This also makes the land self-sustaining.

The Vegetation Unit is characterised by its cost-effective methods and its track record is unparalleled. It is unique in the world in providing a service to members of the mining industry through an organisation such as the Chamber of Mines. It has always been - and continues to be - successful through its team approach. Professionals and other staff members come and go, but the level of service given remains at a consistently high level. Its service stems from its extremely practical approach of the field staff.

Easton points out that before 1965 the development of Johannesburg was heavily skewed to the north of the Ridge. Most of the Vegetation Unit's work was conducted on dumps between 1965 and 1975.
Thereafter, as a result of the abatement of dust from the minedumps, development "exploded" to the south. "The Vegetation Unit has either worked, or advised one every sand dump built," Easton says.

The unit employs a staff varying from 50 to 150 , according to seasonal needs. In days before mechanisation, the unit employed some 700 labourers alone, supervised by about 50 overseers.

The Vegetation Unit is also involved in research through the Water Research Commission into the impact of mining on water quality in the Olifants River above the Loskop Dam.

The unit has maintained its tradition of excellent service to the mining industry through such research programmes and will continue to do so.

It is furthermore involved in a classification system for soils after opencast mining, in conjunction with prof John de Villiers, of the University of Natal and, together with the Atomic Energy Commission is looking into acid mine drainage on colliery spoils. The unit is likely to obtain funds from the Water Research Commission for a study into trees to evaporate polluted water from waste sites.

\section{CLIMATE CHANGE : THE IPCC SCIENTIFIC ASSESSMENT}

The World Meteorological Organization and the United Nations Environmental programme have jointly sponsored an Intergovernmental Panel on Climate Change IPCC). Several hundred scientists from 25 countries have participated in preparing and reviewing the scientific data. The results were published by Cambridge University Press under the editorship of I.T. Houghton, G.J. Jenkins and J.J. Ephraums of The British Meteorological Office during 1990 under the above title.

The local representative of Cambridge University Press, Mr C. Voigt (Tel. 837-2051, fax 837-2271) has arranged for permission to publish excerpts from the book in the next two issues of the Joumal. The excerpt are taken mainly from the Policymaker's Summary of the book. The summary is supported by chapters on various detailed aspects of climate change, each written by express in their respective fields. The result is "the most authoritative and strongly supported statement on climate change that has ever been made by the intemational scientific community".

\section{EXECUTIVE SUMMARY}

\section{We are certain of the following:}

there is a natural greenhouse effect which already keeps the Earth warmer than it would otherwise be.

- emissions resulting from human activities are substantially increasing the atmospheric concentrations of the greenhouse gases: carbon dioxide, methane, chlorofluorocarbons (CFCs) and nitrous oxide. These increases will enhance the greenhouse effect, resulting on average in an additional warming of the Earth's surface. The main greenhouse gas, water vapour, will increase in response to global warming and further enhance it.

We calculate with confidence that:

- some gases are potentially more effective than others at changing climate, and their relative effectiveness can be estimated. Carbon dioxide has been responsible for over half the enhanced greenhouse effect in the past, and is likely to remain so in the future.

atmospheric concentrations of the long-lived gases (carbon dioxide, nitrous oxide and the CFCs) adjust only slowly to changes in emissions. Continued emissions of these gases at present rates would commit us to increased concentrations for centuries ahead. The longer emissions continue to increase at present day rates, the greater reductions would have to be for concentrations to stabilise at a given level.

- the long-lived gases would require immediate reductions in emissions from human activities of over $60 \%$ to stabilise their concentrations at today's levels; methane would require a $15-20 \%$ reduction.

Based on current model results, we predict:

under the IPCC Business-as-Usual (Scenario A) emis- 